\title{
ATTITUDES OF ADULT CONVICTED WOMEN TO EDUCATION IN SLOVAKIA
}

\author{
[POSTOJE DOSPELYCH ODSUDENYCH ZIEN KU VZDELAVANIU \\ NA SLOVENSKU]
}

\section{Dominika Temiakova - Robert Tomsik}

doi: 10.18355/PG.2021.10.1.2

\begin{abstract}
The study presents the attitudes of adult convicted women in a research sample of 186 respondents (29.5\% of respondents from the basic sample) employing the questionnaire method. The research was carried out in 2017 and it was aimed to identify the most significant barriers that prevent convicted women from participating in prison training activities, how their attitudes and overall gross score relate to subjective perceptions of learning difficulty, and to identify the differences in gross attitude scores with respect to participation in discussions, lectures and quizzes. The convicts identified the lack of orientation in learning options and that the learning options do not reflect their needs and interest as the most significant barriers. Based on statistical analysis using Spearman's rho coefficient a statistically significant relationship was found between all attitude statements and subjective perception of learning difficulty (at the level of $\mathrm{p}<0.05$ and $\mathrm{p}<0.01$ ). The strongest correlation was found with the statements "I learn with ease" (rs = $0.460)$, "I want to learn" ( $\mathrm{rs}=-0.412)$, "I know how to learn"( $\mathrm{rs}=-0.432$ ) and the total score $(\mathrm{rs}=-0.441)$. Based on the Mann-Whitey $U$ test significant differences in the gross score of attitudes with respect to participation in all educational activities: discussions $(U=1505,500 ; \mathrm{p}$ $<0.001)$, lectures $(\mathrm{U}=1846,500 ; \mathrm{p}=0.048)$, quizzes $(\mathrm{U}=1654,000 ; \mathrm{p}=$ 0.007) were found - respondents participating in educational activities achieved statistically more significant higher scores.
\end{abstract}

\section{Key words}

convicted women, barriers, attitudes, learning, education, Spearman's rho coefficient, $\mathrm{U}$ - test

\begin{abstract}
Abstrakt
Štúdia prezentuje postoje dospelých odsúdených žien na výskumnej vzorke 186 respondentov $(29,5 \%$ respondentiek zo základného súboru) prostredníctvom metódy dotazníka. Výskum bol realizovaný v roku 2017 a jeho ciel’om bolo zistit' najvýznamnejšie bariéry, ktoré odsúdeným ženám bránia $\mathrm{v}$ účasti na vzdelávacích aktivitách vo výkone trestu, aký je vzt’ah ich postojov a celkového hrubého skóre so subjektívnym vnímaním náročnosti učenia sa, a aké sú rozdiely v miere hrubého skóre postojov vzhl'adom na účast' na besedách, prednáškach a kvízoch. Za najvýznamnejšie bariéry odsúdené označovali pocit nepotrebnosti vzdelávania, nedostatočnú
\end{abstract}


orientáciu v ponuke vzdelávania a ponuku nereflektujúcu ich potreby a záujmy. $\mathrm{Na}$ základe štatistickej analýzy pomocou Spearmanovho rho koeficientu bol zistený štatisticky významný vzt’ah medzi všetkými postojovými výrokmi a subjektívnym vnímaním náročnosti učenia sa (na hladine $\mathrm{p}<0,05$ a p $<0,01)$. Najsilnejší korelačný vzt’ah bol zistený s výrokmi Učím sa $\mathrm{s}$ l'ahkost'ou $\left(\mathrm{r}_{\mathrm{s}}=-0,460\right)$, Chcem sa učit' $\left(\mathrm{r}_{\mathrm{s}}=-0,412\right)$, Viem, ako sa mám učit' $\left(\mathrm{r}_{\mathrm{s}}=-0,432\right)$ a celkovým skóre $\left(\mathrm{r}_{\mathrm{s}}=-0,441\right)$. Na základe MannovhoWhiteyovho U testu sme zistili signifikantné rozdiely $\mathrm{v}$ hrubom skóre postojov vzhl'adom na účast' na všetkých vzdelávacích aktivitách: besedy $(U=1505,500 ; \quad p<0,001)$, prednášky $(U=1846,500 ; \quad p=0,048), \quad k v i ́ z y$ $(\mathrm{U}=1654,000 ; \mathrm{p}=0,007)$ - respondentky zúčastňujúce sa vzdelávacích aktivít získali štatisticky významne vyššie skóre.

\section{Kl'účové slová}

odsúdené, ženy, bariéry, postoje, učenie sa, vzdelávanie, Spearmanov koeficient korelácie, $\mathrm{U}$ - test

\section{1 Úvod}

Vzdelávanie je základným kameňom resocializácie odsúdených. V slovenských i svetových podmienkach je do popredia kladené vzdelávanie, ktorým sa nadobúda kvalifikácia ( $\mathrm{v}$ andragogickej terminológií ide o tzv. druhošancové a d’alšie profesijné vzdelávanie). Takéto vzdelávanie má svoj význam najmä vo vzt'ahu k zamestnatel'nosti a uplatnitel'nosti na trhu práce po prepustení. Odsúdeného však nemožno vnímat' len ako budúceho pracovníka, l’udský zdroj prínosný pre ekonomiku spoločnosti, ale aj ako individuálnu jedinečnú osobnost', ktorá podlieha vlastnému sebarozvoju. Aj S. Lukáčová a kol. (2018: 65) píšu, že „Vzdelávanie dospelých, bez ohl'adu na podmienky, v ktorých prebieha, a ciel'ovú skupinu, by malo mat' aj širšie, nie len inštrumentálne ciele, ktoré sú zamerané na rozvoj zručností pre zamestnatel'nost'. Vzdelávanie nezahŕňa len formovanie zručností; má tiež osobný, sociálny a ekonomický rozmer. Platí to najmä pre vzdelávacie programy vo väzniciach (Warner, 2007), v ktorých je proces sociálnej rehabilitácie považovaný za najdôležitejší."

$\mathrm{Na}$ význam neformálneho vzdelávania $\mathrm{v}$ penitenciárnych podmienkach poukazuje i D. S. Coates (2016: 3) ktorá zdôrazňuje, že „,vzdelávanie vo väzení by malo jedincom poskytnút' zručnosti, ktoré potrebujú k rozširovaniu svojho potenciálu... . Je to jeden z pilierov efektívnej resocializácie. Vzdelávanie by malo budovat' sociálny kapitál a zvyšovat' blahobyt väzňov počas ich trestu“ a, okrem iného, musí podl'a autorky väzenské vzdelávanie pozostávat' aj z „osobnostného a sociálneho rozvoja (Personal and Social Development, PSD), vrátane prevýchovných programov, rodinnej a partnerskej výchovy a praktických zručností (napr. rodičovstvo, financie, vedenie domácnosti)“.

V našich podmienkach vzdelávanie odsúdených, ako jeden z prostriedkov zaobchádzania, upravuje niekol'ko dokumentov, a to Zákon č. 475/2005 Z. z. o výkone trestu odňatia slobody, Vyhláška č. 368/2008 Ministerstva spravodlivosti Slovenskej republiky, ktorou sa vydáva Poriadok výkonu trestu odňatia slobody novelizovaná Vyhláškou č. 500/2013, ktorou sa mení 
a dopĺńa, a Rozkaz generálneho riaditel’a Zboru väzenskej a justičnej stráže č. 7/2009 o vzdelávaní a organizovaní záujmových aktivít a aktivít vo vol’nom čase obvinených a odsúdených.

Zákon č. 475/2005 Z. z. o výkone trestu odňatia slobody (\$32) charakterizuje vzdelávanie odsúdených ako súhrn aktivít založených na aktívnej účasti odsúdeného zameraných na jeho začlenenie do spoločnosti $\mathrm{v}$ súlade $\mathrm{s}$ jeho osobnými a spoločenskými potrebami. Podl’a Vyhlášky č. 368/2008 Ministerstva spravodlivosti Slovenskej republiky, ktorou sa vydáva Poriadok výkonu trestu odňatia slobody (§44), vzdelávanie odsúdených pozostáva zo:

- všeobecnovzdelávacej výučby,

- kultúrnych a športových činností,

- sociálneho vzdelávania,

- bezplatného využívania fondov knižnice.

Novelizácia č. 500/2013 uvedenej vyhlášky (§44) dopĺn̆a, že vymedzené štúdium odsúdeného sa zohl'adňuje v programe zaobchádzania, pričom porušenie povinností sa považuje za jeho neplnenie.

\subsection{Neformálne vzdelávanie odsúdených v prostredí slovenského penitenciárneho systému}

Neformálne vzdelávanie prebieha $\mathrm{v}$ prostredí výkonu trestu odňatia slobody najmä $\mathrm{v}$ podobe hromadných akcií - besied, prednášok a vedomostných kvízov. Tieto patria do tzv. osvetovej činnosti odsúdených, ktorá tvorí z andragogického hl'adiska významnú súčast' záujmového vzdelávania odsúdených. Novelizácia č. 500/2008 Vyhlášky č. 368/2008, ktorou sa vydáva Poriadok výkonu trestu odňatia slobody (§45), definuje osvetovú činnost' ako „,̌innost' zameranú na zvýšenie právneho vedomia, finančnej gramotnosti a sociálnych zručností odsúdeného, rôzne životné a spoločenské problémy, témy z histórie, kultúry, vedy a iných oblastí...". Jej ciel’om je podla Rozkazu č. 7 o vzdelávaní a organizovaní záujmových aktivít a aktivít vo vol’nom čase obvinených a odsúdených (§6) prispiet' $\mathrm{k}$ všestrannému a harmonickému rozvoju osobnosti, rozšririt' a prehĺbit' všeobecné vzdelanie a pomôct' pri rozširovaní duševného obzoru a vedomostí odsúdených. Ako uvádza Vyhláška 368/2008, ktorou sa vydáva Poriadok výkonu trestu odňatia slobody $(2008, \S 45)$, na osvetových podujatiach spolupôsobia odborní zamestnanci ústavu, prokurátori a iné kvalifikované osoby, prípadne záujmové združenia občanov, cirkvi a náboženské spoločnosti a iné organizácie. $\mathrm{Na}$ besedy je možné pozvat' umelcov, športovcov alebo vedeckých pracovníkov. Poverit' vykonaním prednášky alebo besedy je možné aj odsúdeného s odbornou spôsobilost'ou.

Vychádzajúc $\mathrm{z}$ oblastí záujmového vzdelávania dospelých a aktivít realizovaných $\mathrm{v}$ rámci osvetovej činnosti odsúdených v Ústave na výkon trestu odňatia slobody Nitra - Chrenová možno kategorizovat' nasledujúce oblasti záujmového vzdelávania realizované v roku 2016 prostredníctvom besied, prednášok a kvízov:

- kultúry (besedy a prednášky s osobnost’ami kultúrneho a spoločenského života; napr. skupina Horkýže Slíže, muzikálové predstavenie Mamma Mia!, vystúpenie žiakov základnej umeleckej školy), 
- zdravia (témy prvej pomoci, pohlavne prenosných chorôb, bezpečnosti a ochrany zdravia pri práci, zdravého stravovania, prevencie alkoholových a drogových závislostí),

- environmentalistiky (prírodovedné kvízy, geografické kvízy o Slovensku),

- jazykového vzdelávania (kurz základov anglického jazyka),

- sociálneho života (témy prevencie týrania žien, významu a postavenia rodiny v spoločnosti, medzigeneračného spolužitia, právneho vzdelávania, finančného vzdelávania)

- náboženstva a duchovna (aktivity v rámci duchovnej služby $\mathrm{i}$ besedy s obsahom náboženských rozhovorov).

\subsection{Kritériá povol'ovania účasti}

Legislatíva Slovenskej republiky konkrétne vymedzuje možnost' účasti odsúdených na vzdelávaní na základe diferenciačných kritérií, ktoré sa uplatňujú pri regulácií odsúdených. Ide o vonkajšiu diferenciáciu (rozčlenenie jednotlivých ústavov na výkon trestu odňatia slobody podla troch stupňov stráženia), ktorá podl’a Zákona č. 475/2005 Z. z. o výkone trestu odňatia slobody $(\S 5)$ určuje rozdielnost' pohybu, kontaktu, spôsobu zabezpečenia a uplatňovania práv odsúdeného, a vnútornú diferenciáciu (rozčlenenie jednotlivých stupňov stráženia do diferenciačných skupín A otvorené oddelenie, $\mathrm{B}$ - polootvorené oddelenie, $\mathrm{C}$ - uzavreté oddelenie a D - oddiel doživotných trestov).

Podla Vyhlášky č. 368/2008, ktorou sa vydáva Poriadok výkonu trestu odňatia slobody ( $\$ 9$ - 22) možnosti účasti odsúdených na vzdelávacích, osvetových aktivitách a aktivitách vo vol’nom čase môžeme zhrnút' nasledovne:

- ústavy s minimálnym stupňom stráženia - v skupinách A a B sa vytvára vol’ná ponuka aktivít, $\mathrm{v}$ skupine $\mathrm{C}$ o účasti odsúdeného rozhoduje pedagóg,

- ústavy so stredným stupňom stráženia - v skupine A sa vytvára vol'ná ponuka, v skupine $\mathrm{B}$ vhodná ponuka a v skupine $\mathrm{C}$ sa odsúdení na takýchto aktivitách zúčastňujú len so súhlasom pedagóga,

- ústavy s maximálnym stupňom stráženia - v skupine A i B legislatíva umožňuje vytváranie vhodných aktivít, v skupine $\mathrm{C}$ sa do aktivít odsúdený nezarad'uje.

Ako vyplýva $\mathrm{z}$ uvedeného vymedzenia, $\mathrm{z}$ deviatich vnútorných diferenciačných skupín legislatívny rámec priamo povoluje organizovanie a účast' na vzdelávacích, osvetových či vol'nočasových aktivitách siedmim diferenciačným skupinám, teda pomerne širokej časti skupiny odsúdených.

Účast' odsúdených na aktivitách edukačného charakteru je povinná v prípade celoústavných aktivít, ktoré majú osvetový charakter, a sú zamerané na oboznámenie sa s ústavným poriadkom (režim a režimové činnosti, odievanie a ustrojovanie, stravovanie, korešpondencia, a i.).

Vychádzajúc zo štatistík Zboru väzenskej a justičnej stráže možno skonštatovat', že každoročne sa takýchto aktivít zúčastnia priemerne $2 \%$ odsúdených, pričom najvyššia účast' je v rámci vzdelávacích aktivít duchovnej činnosti (priemerne 15\% účast' na prednáškach a besedách a $20 \%$ 
účast' na študijných skupinách). Je nutné však podotknút', že štatistiky zohl'adňujú celoslovenský trend účasti bez ohl'adu na rodové špecifiká.

\subsection{Bariéry a postoje odsúdených ku vzdelávaniu}

Zo štatistických údajov je zrejmé, že priemerná účast' dospelých odsúdených mužov i žien na d'alšom vzdelávaní na Slovensku je extrémne nízka - na všetkých druhoch vzdelávania v rámci formálnych i neformálnych učebných činností je to len priemerne cca $6 \%$; pre porovnanie ,prieskum väzenského vzdelávania a prípravy v Európe v roku 2012 ukázal, že vo väčšine štátov Európskej únie bola účast' väzňov na väzenskom vzdelávaní a príprave nižšia ako 25\%“ (M. Crowley, 2019: 09). Dôvodov môže byt' niekol'ko; od prístupu cez ponuku až po postoje odsúdených ku vzdelávaniu. Faktory, ktoré svojim charakterom možno zaradit' medzi bariéry brániace odsúdeným v účasti na vzdelávaní popísal už K. Novák (1986: 75); podmienky izolácie (a z neho vyplývajúci pocit beznádejnosti, ktorý výrazne ovplyvňuje proces učenia sa), časový odstup (strata zvyku učit' sa a koncentrovat' svoju pozornost'), negatívny vzt’ah $\mathrm{k}$ učeniu (napríklad negatívna skúsenost' počas povinnej školskej dochádzky) a psychické odchýlky (anomálie rôzneho psychického charakteru). Medzi d'alšie faktory C. Rose (2004) zarad'uje súčasné politiky, dostupnost' programov a kvalitu programov.

My bariéry vo vzdelávaní odsúdených kategorizujeme nasledovne:

- typické bariéry, ktoré sa však v prostredí výkonu trestu takmer úplne stierajú - časová a finančná náročnost', množstvo povinností, cestovanie za vzdelávaním, problematická orientácia $\mathrm{v}$ ponuke vzdelávania,

- bariéry vyplývajúce zo systému vzdelávania danej inštitúcie - ponuka vzdelávania nereflektujúca vzdelávacie potreby a záujmy odsúdených, striktný výber do vzdelávacích aktivít,

- vnútorné bariéry - negatívny postoj k učeniu (sa), absencia vzdelávacích návykov, nepresvedčenie o význame vzdelávania, pochybnosti o schopnostiach k učeniu (sa), nízka sebaúcta a sebadôvera odsúdeného.

Za najvýznamnejšiu bariéru považujeme postoj odsúdeného k vzdelávaniu, pretože tento je agensom zmien, významným motivačným činitel'om ovplyvňujúcim správanie jednotlivca. Vzhl'adom na ciel' vzdelávania odsúdených je ich postoj ku vzdelávaniu predpokladom úspešnej resocializácie a adaptácie na život po prepustení z výkonu trestu odňatia slobody, a to nie len z aspektu uplatnitel'nosti na trhu práce. Ako uvádzajú M. Urbanová, M. Večeřa (2003: 239) „Postoj je spájaný najmä s motiváciou subjektu ku konaniu a naviazaný viac na záujmy a potreby. Postoj v sebe zahŕňa zložku kognitívnu, afektívnu a snahovo akčnú. Z hl'adiska času sú relatívne stabilné, hlbšie osobnostne zakotvené a naviazané na základné hodnotové orientácie jedinca."

J. Oravcová (2004: 168 - 169) charakterizuje zložky postoja nasledovne:

- kognitívna (poznávacia) - je spojená s rozumovým hodnotením predmetu postoja, vyjadruje jeho hodnotu a vytvára sa najčastejšie preberaním názorov od iných l'udí,

- emocionálna (citová) - vyjadruje citový vzt’ah k predmetu postoja, je utváraná osobnou skúsenost'ou s predmetom postoja, 
- konatívna - prejavuje sa v tendencii konat', reagovat' určitým spôsobom na predmet postoja, táto zložka vyplýva $\mathrm{z}$ dvoch predchádzajúcich zložiek.

\section{Výskum}

Výskum postojov kučeniu sa prípadne vzdelávaniu odsúdených nebol v našich podmienkach realizovaný. V Českej republike prebehol v roku 2002 ojedinelý výskum, ktorý, okrem hodnotových preferencií odsúdených žien, zistoval i postoje odsúdených žien, avšak k právu a jeho dodržovaniu (právne postoje). Prebiehal dotazníkovou metódou na vzorke 322 respondentiek v štyroch českých väzniciach. Naše výskumné zistenia teda nie je možné komparovat', čo patrí spolu s nemožnost'ou využitia štandardizovaného výskumného nástroja $\mathrm{z}$ dôvodu jeho neexistencie a osobnostnými špecifikami výskumnej vzorky k limitom výskumu.

\subsection{Ciele}

Vychádzajúc z uvedených východísk sme vo výskume stanovili nasledovné výskumné otázky:

$\mathrm{VO}_{1}$ : Aké sú najvýznamnejšie bariéry vo vzdelávaní odsúdených žien?

$\mathrm{VO}_{2}$ : Aký je vzt’ah jednotlivých položiek (postojov) a celkového hrubého skóre so subjektívnym vnímaním náročnosti učenia sa?

$\mathrm{VO}_{3}$ : Aké sú rozdiely v miere hrubého skóre postojov vzhl'adom na účast' na besedách, prednáškach a kvízoch realizovaných $\mathrm{v}$ rámci penitenciárnej edukácie?

\subsection{Metódy}

Vo výskume bol použitý dotazník autorskej proveniencie. Ten bol po osobnom doručení do ústavu $\mathrm{v}$ printovej forme administrovaný odsúdeným ženám priamo zamestnancami (riaditel' oddelenia výkonu trestu, príslušníci na funkčnom mieste pedagóg). Pozostával z 25 položiek; 4 z nich boli sociodemografického charakteru (vek, dosiahnuté vzdelanie, rodinný stav a počet detí). Položky boli najmä uzavretého a polouzavretého charakteru s výberom odpovedí, dve položky boli škálovacie (štvorstupňová a pät'stupňová škála). Výskumný nástroj bol primárne zameraný na vzdelávanie odsúdených žien v ústave na výkon trestu odňatia slobody, ale aj na ich hodnoty a postoje ku vzdelávaniu. Cronbachova alfa dotazníka je $\alpha=$ 0.764 .

$\mathrm{Na}$ zistenie odpovedí na deskriptívnu VO1 sme v dotazníku použili polouzavretú položku, ktorá sa pýtala na dôvody, ktoré odsúdeným bránia $\mathrm{v}$ účasti na vzdelávacích aktivitách a kultúrno-osvetovej činnosti v ústave. Vychádzajúc z popísaných teoretických východísk ponúkala 16 alternatív a vol'nú odpoved', pričom respondentky mohli označit' viacero možností. Pre empirickú analýzu postojov (VO2) bola vo výskumnom nástroji použitá škálovacia položka pozostávajúca $\mathrm{z}$ dvanástich výrokov vzt’ahujúcich sa $\mathrm{k}$ jednotlivým zložkám postoja, ktoré respondentky hodnotili na pät'stupňovej škále (1 - určite áno; 2 - áno; 3 - neviem; 4 - nie; 5 - určite nie). Škála postojov $\mathrm{k}$ učeniu sa a vzdelávaniu bola zostavená $\mathrm{z}$ dvanástich kladne naformulovaných jednoduchých výrokov (pozri Tabul'ku 1). 
Reliabilita vnútornej konzistencie škály je $\mathrm{C} \alpha=0,867$. Na stanovenie adekvátnosti vzorky dát pre faktorovú analýzu bol použitý KMO - Kaiser Meyer Olkin test. Čím viac sa blíži k 1, tým je vhodnejšia, a tu nadobudla hodonotu $\mathrm{KMO}=0,850$. Škálovanie tejto položky sme dávali do štatistického vzt’ahu k subjektívnemu vnímaniu náročnosti učenia sa, ktoré bolo zistované d’alšou uzavretou škálovacou položkou (Učenie sa je pre Vás: 1 - vel'mi jednoduché; 2 - jednoduché; 3 - niekedy jednoduché, niekedy náročné; 4 náročné; 5 - vel'mi náročné).

Proces zist'ovania VO3 pozostával z výpočtu štatistického rozdielu medzi hrubým skóre škálovacej položky postojov a položky zistujúcej frekvenciu účasti respondentiek na jednotlivých druhoch vzdelávacích aktivít, ktoré sú zákonom povol'ované a realizované $\mathrm{v}$ ústavoch na výkon trestu odňatia v Slovenskej republike, vrátane prednášok, besied a kvízov, a to za obdobie roka 2016 (dáta boli zbierané v prvom štvrtroku 2017).

\subsection{Výskumný súbor}

Výkon trestu odňatia slobody odsúdených žien prebieha v Slovenskej republike primárne $\mathrm{v}$ dvoch špecializovaných ústavoch - Ústav na výkon trestu odňatia slobody Levoča (kapacita 112 miest) a Ústav na výkon trestu odňatia slobody Nitra - Chrenová (kapacita 354 miest), v ktorom výskum prebiehal. V roku 2017, kedy prebiehal zber dát, bolo na Slovensku odsúdených celkovo 630 žien (základný súbor, Ročenka Zboru väzenskej a justičnej stráže za rok 2017, 2018).

Výskumnú vzorku tvorilo 186 dospelých žien, čo predstavuje percentuálny podiel 29,5\% (takmer 1/3 respondentiek základného súboru). V období zberu dát bol priemerný počet odsúdených žien v Ústave na výkon trestu odňatia slobody Nitra-Chrenová 252, na výskume tak participovalo až 73,8\% odsúdených žien z ústavu. Výskumný súbor bol tvorený odsúdenými ženami vykonávajúcimi trest odňatia slobody vo všetkých troch stupňoch stráženia.

Priemerný vek respondentiek bol 38,43 rokov (Min=20; Max=66; $\mathrm{Sd}=10,529)$, a priemerná dížka výkonu trestu bola $\mathrm{M}=61,08$ mesiacov (Min=3; Max=324; $\mathrm{Sd}=55,845$ ), resp. $\mathrm{M=5,09}$ rokov. Vzdelanostná úroveň respondentiek bola heterogénna; základné vzdelanie (ISCED 2A) malo dosiahnuté až $50 \%$ respondentiek, stredoškolské vzdelanie bez maturity (ISCED 3C) a stredoškolské vzdelanie s maturitou (ISCED 3A; 3B) dosiahlo $16,12 \%$ respondentiek, a vysokoškolské vzdelanie (ISCED 6; 7) len viac ako $2,5 \%$ respondentiek.

\section{4 Štatistické spracovanie}

Dáta boli spracované pomocou programu SPSS ver. 22 for Windows. Boli použité metódy deskriptívnej (N, M, SD, SK, KU) a inferenčnej štatistiky: testy normality distribúcie dát, korelačné a komparačné testy. Pre zistenie vzt’ahu medzi premennými bol použitý Spearmanov koeficient korelácie, a pre zistenie rozdielov vzhl'adom na výskumné podskupiny bol použitý MannWhitney $\mathrm{U}$ test (na základe výsledkov D'Agostinovho $\mathrm{K}^{2}$ testu normality distribúcie dát; Tomšik: 2017). 


\section{Výsledky}

$\mathrm{V}$ prvej časti interpretácie výsledkov sa zameriame na deskripciu bariér v účasti na d’alšom vzdelávaní, ktoré odsúdené vnímajú ako najvýznamnejšie (VO1). Najpočetnejšie označované bariéry, ktoré odsúdeným bránia $v$ účasti na vzdelávacích aktivitách $\mathrm{v}$ penitenciárnom prostredí, boli vnútorné bariéry $(36,52 \%)$. Z nich je najvýznamnejší subjektívny pocit nepotrebnosti vzdelávania (12,36\%), prekážkami je aj časový odstup od učenia a zdravotný stav (obe po cca $5 \%$ ). Spomedzi typických bariér sa ako najvýznamnejšia ukázala nedostatočná orientácia odsúdených $\mathrm{v}$ ponuke vzdelávania $\mathrm{v}$ ústave $(11,29 \%)$. V oblasti systémových bariér odsúdené najčastejšie označovali dôvod ich neúčasti to, že ústav neponúka takéto aktivity (13,97\%) resp. že žiadny z kurzov ich nezaujal (9,67\%). Medzi „iné dôvody“ odsúdené uvádzali nedostatok súkromia a z neho vyplývajúcu neschopnost' sústredit' sa, eskorty či časté neprítomnosti $\mathrm{v}$ ústave, ako aj subjektívny pocit dostatočnej vzdelanosti. Výsledky sú v Grafe 1.

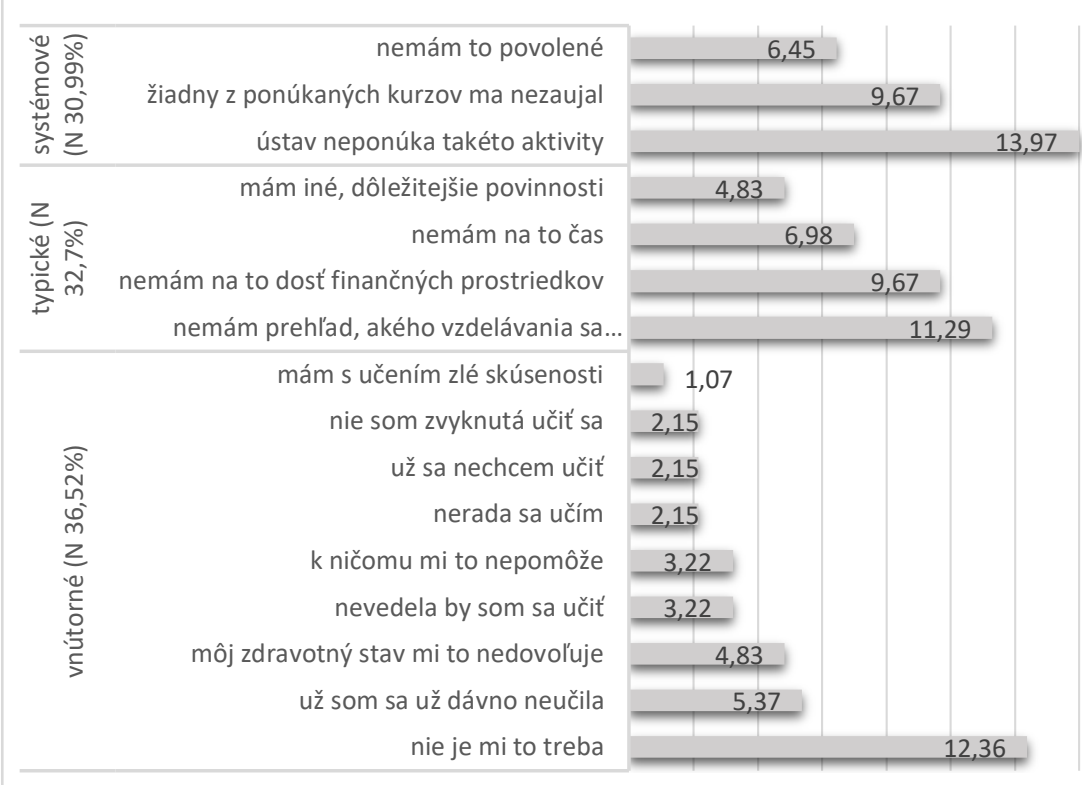

\section{Graf 1: Percentuálny podiel významnosti bariér $\mathrm{v}$ účasti na vzdelávaní odsúdených žien}

V druhej časti interpretácie výsledkov (VO2) sa zameriame na analýzu opisnej štatistiky jednotlivých premenných (postojov) a ich vzt’ahom, so subjektívnym vnímaním náročnosti učenia sa (Učenie sa je pre Vás: 1 vel'mi jednoduché; 5 - vel'mi náročné). Respondentky odpovedali na škále 14 (1 - rozhodne nie; 4 - rozhodne áno) mierou súhlasu s jednotlivými výrokmi. Priemerné skóre sa pohybovalo od $M=3,81$ do $M=4,69$. Najnižšie skórované premenné ( $\mathrm{M}<4,00$ body) boli výroky Učenie mi nikdy nerobilo 
problém $(\mathrm{M}=3,81 ; \mathrm{Sd}=1,082)$ a Uč́m sa s lahkostou $(\mathrm{M}=3,87 ; \mathrm{Sd}=0,995)$. Ostatné výrok boli skórované $\mathrm{v}$ priemere nad $\mathrm{M}>4,00$, konkrétne najvy̌šsie boli skórované výroky Vzdelanie je hodnota $(\mathrm{M}=4,55 ; \mathrm{Sd}=0,629)$ a Človek $s a$ uči celý život, aj $v$ dospelosti a starobe $(\mathrm{M}=4,69 ; \mathrm{Sd}=0,543)$. Pri oboch výrokoch boli namerané priemerné hodnoty nad $M>4,50$. V̌seobecne však môžeme konštatovat', že všetky premenné boli skórované pomerne vysoko, vzhl'adom na možné rozpätie bodov.

V d’alšej analýze sme zist'ovali vzt’ah jednotlivých položiek a celkového hrubého skóre so subjektívnym vnímaním náročnosti učenia sa. Na základe štatistickej analýzy pomocou Spearmanovho rho koeficientu bol zistený štatisticky významný vzt'ah medzi všetkými výrokmi a hrubým skóre (na hladine $\mathrm{p}<0,05$ a $\mathrm{p}<0,01)$. Korelačné koeficienty sa pohybovali od $\mathrm{r}_{\mathrm{s}}=-0156$ do $\mathrm{r}_{\mathrm{s}}=-0,460$. Najsilnejší korelačný vztah bol zistený s výrokmi Uč́m $s a$ s l'ahkostou $\left(\mathrm{r}_{\mathrm{s}}=-0,460\right)$, Chcem sa učit' $\left(\mathrm{r}_{\mathrm{s}}=-0,412\right)$, Viem, ako sa mám učit' $\left(r_{s}=-0,432\right)$ a celkovým skóre $\left(r_{s}=-0,441\right)$. Najslabšie vzt'ahy boli zistené s položkami Učenie mi nikdy nerobilo problém $\left(\mathrm{r}_{\mathrm{s}}=-0,156\right)$, Vyššie vzdelanie mi zabezpeči lepši život po prepusteni $\left(\mathrm{r}_{\mathrm{s}}=-0,194\right)$, a Ak by bol kurz, ktorý by ma zaujal, prihlásila by som sa $\left(\mathrm{r}_{\mathrm{s}}=-0,183\right)$, ktoré korelujú so subjektívnym vnímaním náročnosti učenia sa na hladine 0,01 . Výsledky sú uvedené $\mathrm{v}$ Tabul'ke 1.

Tabul'ka 1: Opisná štatistika výskumných premenných (položková analýza a celkové hrubé skóre) a ich korelácia so subjektívnym vnímaním náročnosti učenia sa.

\begin{tabular}{|c|c|c|c|c|c|c|}
\hline & $\mathrm{N}$ & $\mathrm{M}$ & SD & SK & KU & $r s$ \\
\hline $\begin{array}{l}\text { Učenie mi nikdy nerobilo } \\
\text { problém. }\end{array}$ & 166 & 3,81 & 1,082 & $-0,841$ & 0,046 & $-0,156^{*}$ \\
\hline Učím sa s l'ahkost'ou. & 166 & 3,87 & 0,955 & $-0,928$ & 0,759 & $-0,460^{* *}$ \\
\hline $\begin{array}{l}\text { Rada sa učím a môj vzt'ah k } \\
\text { učeniu je dobrý. }\end{array}$ & 166 & 4,00 & 0,947 & $-0,997$ & 0,819 & $-0,401^{* *}$ \\
\hline $\begin{array}{l}\text { Vyššie vzdelanie mi } \\
\text { zabezpečí lepší život po } \\
\text { prepustení. }\end{array}$ & 170 & 4,15 & 1,055 & $-1,321$ & 1,225 & $-0,194^{*}$ \\
\hline Chcem sa učit'. & 163 & 4,17 & 0,841 & $-1,205$ & 1,660 & $-0,412^{\text {*** }}$ \\
\hline $\begin{array}{l}\text { Ked' sa naskytne príležitost' } \\
\text { naučit' sa niečo nové a } \\
\text { užitočné, vždy ju využijem. }\end{array}$ & 167 & 4,19 & 0,833 & $-0,993$ & 0,664 & $-0,221^{* *}$ \\
\hline Viem, ako sa mám učit? & 169 & 4,26 & 0,692 & $-1,051$ & 2,709 & $-0,432^{* *}$ \\
\hline $\begin{array}{l}\text { Ak by bol kurz, ktorý by ma } \\
\text { zaujal, prihlásila by som sa. }\end{array}$ & 168 & 4,42 & 0,678 & $-0,975$ & 0,715 & $-0,194^{*}$ \\
\hline $\begin{array}{l}\text { Je rozumné vzdelávat' sa, } \\
\text { ked’ mám príležitost'. }\end{array}$ & 170 & 4,45 & 0,705 & $-1,398$ & 2,325 & $-0,320^{* *}$ \\
\hline $\begin{array}{l}\text { Páči sa mi, ked'sa naučím } \\
\text { niečo nové. }\end{array}$ & 170 & 4,48 & 0,598 & $-1,191$ & 2,913 & $-0,183^{*}$ \\
\hline Vzdelanie je hodnota. & 165 & 4,55 & 0,629 & $-1,538$ & 3,182 & $-0,364^{* *}$ \\
\hline
\end{tabular}




\begin{tabular}{|l|c|c|c|c|c|c|}
\hline $\begin{array}{l}\text { Človek sa učí celý život, aj v } \\
\text { dospelosti a starobe. }\end{array}$ & 175 & 4,69 & 0,543 & $-2,007$ & 5,475 & $-0,247^{* *}$ \\
\hline $\begin{array}{l}\text { Postoje k učeniu (Celkové } \\
\text { skóre) }\end{array}$ & 139 & 55,72 & 6,435 & $-0,390$ & $-0,362$ & $-0,441^{* *}$ \\
\hline
\end{tabular}

Pozn.: N- počet; M- priemer; Sd- štandardná odchýlka; SK- šikmost'; KUšpicatost'; $\mathrm{r}_{\mathrm{s}}$ - korelačný koeficient; *- korelácia je signifikantná na hladina $\mathrm{p}<0,05$.**- korelácia je signifikantná na hladine $\mathrm{p}<0,01$.

Ďalším ciel'om výskumu (VO3) bolo zistit' rozdiely v miere hrubého skóre postojov vzhl'adom účast' na besedách, prednáškach a kvízoch realizovaných v rámci penitenciárneho vzdelávania:

- besied sa minimálne raz zúčastnilo $\mathrm{N}=53(38,1 \%)$ respondentiek a N=83 $(59,7 \%)$ sa ich nikdy nezúčastnilo,

- prednášok sa minimálne raz zúčastnilo $\mathrm{N}=87$ (62,6\%) respondentiek a $\mathrm{N}=52(37,4 \%)$ sa ich nikdy nezúčastnilo,

- kvízov sa minimálne raz zúčastnilo $\mathrm{N}=86$ (61,9\%) respondentiek a N=53 $(38,1 \%)$ sa ich nikdy nezúčastnilo.

Vzhl'adom na to, že sa niektoré respondentky jednotlivých vzdelávacích aktivít zúčastnili viac než raz, súčet zúčastnených aktivít je podstatne vyšší ako počet respondentiek (besedy boli absolvované 217 krát, prednášky 519 krát a kvízy 252 krát). Na základe Mannovho-Whiteyovho U testu sme zistili signifikantné rozdiely $\mathrm{v}$ hrubom skóre postojov vzhl'adom na účast' na všetkých vzdelávacích aktivitách: besedy $(U=1505,500 ; p<0,001)$, prednášky ( $U=1846,500 ; p=0,048)$, kvízy $(U=1654,000 ; p=0,007)$. Vo všetkých prípadoch respondentky zúčastňujúce sa týchto vzdelávacích aktivít získali štatisticky významne vyššie skóre v celkovom hrubom skóre postojov v porovnaní s respondentkami, ktoré sa vzdelávacích aktivít nezúčastňovali. Výsledky sú uvedené v Tabul'ke 2 nižšie.

Tabul'ka 2: Rozdiely v miere hodnôt vzhl'adom na účast' respondentiek na besedách, prednáškach a kvízoch (U test).

\begin{tabular}{|c|c|c|c|c|c|c|c|}
\hline \multicolumn{2}{|c|}{} & $\mathrm{N}$ & $\mathrm{Mr}$ & $\mathrm{Sr}$ & $d f$ & $U$ & $p$ \\
\hline \multirow{2}{*}{ Besedy } & NIE & 83 & 60,14 & 4991,50 & \multirow{2}{*}{137} & \multirow{2}{*}{1505,500} & $<0,001$ \\
\cline { 2 - 6 } & ÁNO & 56 & 84,62 & 4738,50 & & & \\
\hline \multirow{2}{*}{ Prednášky } & NIE & 52 & 62,01 & 3224,50 & \multirow{2}{*}{137} & \multirow{2}{*}{1846,500} & 0,048 \\
\cline { 2 - 6 } & ÁNO & 87 & 74,78 & 6505,50 & & & \multirow{2}{*}{137} \\
\hline \multirow{2}{*}{ Kvízy } & NIE & 86 & 62,73 & 5395,00 & \multirow{2}{*}{1654,000} & 0,007 \\
\cline { 2 - 5 } & ÁNO & 53 & 81,79 & 4335,00 & & & \\
\hline
\end{tabular}

Pozn.: N- počet; M- priemer; Sd- štandardná odchýlka; Mr- priemer poradových čísel; Sr- súčet poradových čísel; df- stupne vol’nosti; UMannov-Whitneyov U test; p- hladina štatistickej významnosti. 


\section{Diskusia}

Za najvýznamnejšie bariéry brániace dospelým odsúdeným ženám na vzdelávaní sa vo výskume ukázali nedostatočná orientácia odsúdených v ponuke vzdelávania $(11,29 \%)$, nedostatočná ponuka aktivít $(13,97 \%)$ resp. nezáujem o ponúkané aktivity $(9,67 \%)$. Tieto bariéry možno minimalizovat' najrýchlejšie a najjednoduchšie, a to zo strany príslušníka na funkčnom mieste pedagóg (povereného vzdelávaním, povereného kultúrno-osvetovou činnost'ou), ktorý je za oblast' vzdelávania odsúdených zodpovedný, a tiež zohl'adňovaním vzdelávacích potrieb a záujmov odsúdených pri koncipovaní vzdelávacej ponuky. Závažnejšou bariérou je však subjektívny pocit nepotrebnosti vzdelávat' sa, ktorý súvisí s postojmi odsúdených žien ku vzdelávaniu, nakol'ko zmena postojov je náročný a dlhodobý proces. Zistené bariéry v účasti na vzdelávaní slovenských odsúdených sú však v zhode s trendom EU. Ako uvádza M. Crowley (2019: 9) „Zistenia z prieskumu v roku 2012 ukázali, že najčastejšími prekážkami v účasti žien na vzdelávaní boli nedostatok motivácie a predchádzajúce negatívne skúsenosti so vzdelávaním. Ďalšími bariérami boli vyššia stimulácia $\mathrm{k}$ práci vo väzení než ku vzdelávaniu, obmedzený počet kapacít a ponuka programov, ktoré neboli v zhode s dížkou trvania trestu (napríklad pre väzenkyne s kratšou dížkou trestu)." Identifikovat' bariéry vo vzdelávaní dospelých však nestačí, preto súhlasíme s C. Rose (2004: 78) že ,....hoci tieto štrukturálne faktory môžu napomôct' k nášmu chápaniu tohto fenoménu, neponúkajú kompletný obraz. Pretože je o unikátnych a osobných motiváciách odsúdených, ktoré prelomili štrukturálne bariéry, známe vel'mi málo, tvrdím, že je potrebné vyvinút' nové metodiky riešiace tieto problémy."

Z hl'adiska jednotlivých zložiek postoja boli najvyššie skórovaná kognitívna zložka (priemerné skóre 4,41) potom emocionálna (resp. afektívna, priemerné skóre 4,33) a najnižšie bola skórovaná zložka konatívna (resp. snahovo akčná, priemerné skóre 4). Možno teda konštatovat', že odsúdené vzdelávanie a učenie sa rozumovo hodnotia kladne uvedomujúc si jeho význam, vyjadrujú navonok pozitívny citový vzt’ah $\mathrm{k}$ učeniu sa a vzdelávaniu, avšak v oblasti konania a reagovania je ich postoj slabší. Inak povedané - odsúdené vedia, že vzdelávat' sa je dôležité, avšak sa ho vo vel'kej miere nezúčastňujú, pričom dôvody v podobe bariér boli popísané. Taktiež sa potvrdilo, že odsúdené, ktoré sa zúčastňovali neformálneho vzdelávania $\mathrm{v}$ podobe besied, prednášok a kvízov $\mathrm{v}$ penitenciárnom prostredí štatisticky významne vyššie skórovali postojové výroky ako odsúdené, ktoré sa týchto aktivít nezúčastňovali, na základe čoho možno konštatovat', že odsúdené, ktoré sa zúčastňujú vzdelávacích aktivít majú pozitívnejší celkový postoj ku vzdelávaniu. Ukazuje sa teda, že ak majú odsúdené možnost' a príležitost' zúčastňovat' sa vzdelávania vo výkone trestu, vrátane toho neformálneho, ovplyvňuje to ich celkový postoj $\mathrm{k}$ učeniu sa i vzdelávaniu. Preto je nevyhnutné odsúdené zapájat' do vzdelávania a minimalizovat' akékol’vek bariéry, ktoré im vo vzdelávaní bránia.

\section{Záver}


V slovenských podmienkach dodnes výskum odsúdených žien absentuje. Pozornost' autorov sa zameriava najmä na osoby prepustené z výkonu trestu odňatia slobody, čoho dôvodom môže byt' lepší a jednoduchší prístup $\mathrm{k}$ respondentom. Obdobná situácia platí aj v Českej republike. Urbanová, Večeřa (2003) však upozorňujú, že takéto podceňovanie ženskej kriminality predstavuje nebezpečenstvo, pretože aj ked' sa ženy dopúštajú menej závažných trestných činov, ich morálne dopady sú závažnejšie. Vo výskume odsúdených žien všeobecne tak dodnes platí, že „,ako mnoho výskumníkov upozorn̆uje, [ženy] zostávajú vo výskume a praxi väzenstva na okraji záujmu.“" (Moore, Scraton 2014, in Crewe, Hulley, Wright, 2017: 1374). Tento stav je nevyhnutné menit', pretože len výskumom je možné porozumiet' svetu odsúdených žien, ktorý sa značne líši od sveta odsúdených mužov, a tým zefektívňovat' nie len metódy resocializácie, ale i celkový spôsob zaobchádzania a výkonu trestu. Ako upozorn̆ujú aj Kruttschnitt, Gartner (2003: 1) ,pochopenie spôsobov, ako ženy spracovávajú moc a budujú si život vo väzení je významnejší, než v minulosti; nové teoretické rámce poskytli dôležité poznatky, základné otázky však zostávajú nezodpovedané.“

\section{Bibliographic references}

COATES, D. S. 2016. Unlocking Potential. A review of education in prison. London: Ministry of Justice.

CREWE, B. - HULLEY, S. - WRIGHT, S. 2017. The Gendered Pains of Life Imprisonment. In: The British Journal of Criminology, vol. 57, n. 6, pp. 1359-1378. ISSN 1464-3529.

CROWLEY, M. 2019. The rehabilitation and social reintegration of women prisoners. Implementation of the Bangkok rules.London: Penal Reform International. ISBN 9781909521650.

KRUTTSCHNITT, C., GARTNER, R. 2003. Women's Imprisonment. In: Crime and Justice, vol. 30, n. 3, pp. 1-81. ISSN 0192-3234.

LUKACOVA, S. - LUKAC, M. - PIROHOVA, I. - LUKAC, E. HARTMANNOVA, L. 2018. Prison education in Slovakia from the teacher's perspective. In: Journal of Prison Education and Reentry, vol. 5, n. 1, pp. 6379. ISSN 2387-2306.

ORAVCOVA, J. 2004. Socialna psychologia. Banska Bystrica: UMB. ISBN 8080559805.

Rocenka Zboru vazenskej a justicnej straze za rok 2017. 2018. Bratislava.

ROSE, C. 2004. Women's Participation in Prison Education: What We Know and What We Don't Know. In: Journal of Correctional Education, vol. 55, n. 1, pp. 78100. ISSN 0740-2708.

ROZKAZ c. 7 o vzdelavani a organizovani zaujmovych aktivit a aktivit vo volnom case obvinenych a odsudenych. 2009. 19 p.

TOMSIK, R. 2017. Kvantitativny vyskum v pedagogickych vedach: uvod do metodologie a statistickeho spracovania. Nitra: UKF. ISBN 978805581206 9 .

URBANOVA, M. - VECERA, M. 2003. Zenska kriminalita - hodnotove orientace a postoje $\mathrm{k}$ pravu delikventnich zen. In: Casopis pro pravni vedu a praxi, vol. 11, n. 3, pp. 232-240. ISSN 1805-2789. 
VYHLASKA c. 368/2008 Ministerstva spravodlivosti Slovenskej republiky, ktorou sa vydava Poriadok vykonu trestu odnatia slobody v zneni neskorsich predpisov

VYHLASKA c. 500/2013 Ministerstva spravodlivosti Slovenskej republiky, ktorou sa meni a doplna vyhlaska Ministerstva spravodlivosti Slovenskej republiky c. 368/2008, ktorou sa vydava Poriadok vykonu trestu odnatia slobody $\mathrm{v}$ zneni neskorsich predpisov

ZAKON c. $475 / 2005$ Z. z. o vykone trestu odnatia slobody v zneni neskorsich predpisov

ZAKON c. $370 / 2013$, ktorym sa meni a doplna zakon c. $475 / 2005$ Z. z. o vykone trestu odnatia slobody $\mathrm{v}$ zneni neskorsich predpisov

PhDr. Dominika Temiaková, PhD.

Department of Pedagogy

Faculty of Education

Constantine the Philosopher University

Dražovská cesta 4, 94901 Nitra

Slovakia

dtemiakova@ukf.sk

PaedDr. Robert Tomšik, PhD.

Research Institute for Child Psychology and Pathopsychology

Cyprichova 42

Bratislava

Slovakia

robert.tomsik@vudpap.sk 